\title{
Josiah Royce Influenced Charles Peirce
}

\author{
David E. Pfeifer
}

\section{OpenEdition}

\section{Journals}

Electronic version

URL: http://journals.openedition.org/ejpap/659

DOI: 10.4000/ejpap.659

ISSN: 2036-4091

\section{Publisher}

Associazione Pragma

\section{Electronic reference}

David E. Pfeifer, « Josiah Royce Influenced Charles Peirce », European Journal of Pragmatism and American Philosophy [Online], VIII-2 | 2016, Online since 16 January 2017, connection on 19 April 2019. URL : http://journals.openedition.org/ejpap/659; DOI : 10.4000/ejpap.659

This text was automatically generated on 19 April 2019

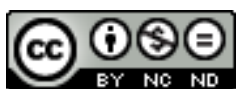

Author retains copyright and grants the European Journal of Pragmatism and American Philosophy right of first publication with the work simultaneously licensed under a Creative Commons AttributionNonCommercial-NoDerivatives 4.0 International License. 


\title{
Josiah Royce Influenced Charles Peirce
}

\author{
David E. Pfeifer
}

Josiah Royce (born 10 November 1855) was sixteen years younger than Charles Peirce (born 10 September 1839). Most often, senior scholars influence younger scholars. This view seems common. On the surface, reading histories and biographies, it appears that while Peirce influenced Royce, Royce did not have any impact on Peirce. For example, the superb history of American Philosophy by Elizabeth Flower and Murray Murphey (1977) has no mention of Royce in the Peirce chapter, but has numerous Peirce references in the Royce chapter. Even the meticulous Max Fisch wrote: "Royce was [...] acquainted with Peirce, followed his work with increasing interest, and was increasingly influenced by it" (Fisch 1951: 3). The standard biographies of Royce ${ }^{1}$ and Peirce ${ }^{2}$ do not indicate Royce had an influence on Peirce. A strong example of this view is expressed by Frank Oppenheim, the dean of Royce scholars, who wrote:

Royce experienced Charles Peirce's Cambridge Conferences of 1898 as epochmaking, since "they started me on such new tracks [Letter of 21 June 1901 to William James]." [Royce integrated] Peirce's ideas of continuity, individuality, infinity, system, and the logic of relatives into his own idea of individuality [...] After a stroke in early February 1912, a recuperating Royce, temporarily relieved from teaching, carefully compared and contrasted the early, middle, and late published writings of "our American logician," Charles Peirce. In this way Royce grasped Peirce's theories of signs, interpretation, and his three categories far more profoundly than previously. (Oppenheim 2004,118-9)

Even Douglas Anderson in his masterful article, "Who's a Pragmatist: Royce and Peirce at the Turn of the Century," says, "I take as given [...] the fact that Peirce influenced Royce's thought in some important ways," (2005: 473) without discussing how Royce may have influenced Peirce. Mary Mahowald in her insightful study of Royce's Idealistic Pragmatism states:

That Charles Peirce and William James, both well known pragmatists, exerted an important influence on the philosophy of Royce is evident from the biographical data, from cross references in their works, and from their correspondence, both published and unpublished. In general the relationship of Royce to Peirce may be 
characterized as one of deference, his relationship to James as one of friendship.

(Mahowald 1972: 17) 3 books and articles by Ludwig Nagl (2004), Frank Oppenheim (2005), Randall Auxier (2013), and Cheryl Misak (2013). ${ }^{4}$ However, none of these authors makes a definite claim that Royce influenced Peirce. Auxier (2013: 13) states that "the direction of influence is undecidable in many cases."

4 I would like to tell a tale of Josiah Royce influencing Charles Peirce, a narrative worthy of presentation, since Royce had a stronger influence on Peirce than many might realize. The first section of this paper is history, a chronology; 5 the second section is a summary of how Peirce's thought changed because of this instance of Royce's influence. ${ }^{6}$

\section{Chronology}

Josiah Royce and Charles Peirce knew of each other through Johns Hopkins University, though not directly. Royce was at Johns Hopkins 1876-1878, receiving his Ph.D. in 1878. Peirce taught at the university 1879-1884. They knew of each other's writings, and of course were associated through William James. Here are some examples of their meetings, at least through writings. Frank Oppenheim points out that at the 20 May 1880 meeting of the Johns Hopkins University Metaphysical Club, Peirce was elected President and the club heard Royce's paper entitled "On Purpose in Thought" (Oppenheim 2005: 14).? In 1885, Peirce seriously studied Royce's The Religious Aspect of Philosophy, writing a review $^{8}$ for the Popular Science Monthly that was never published. While greatly praising Royce, Peirce chided him for being too Hegelian. In 1899, a change in Peirce's thought about Royce came when Peirce read and reviewed Royce's The World and the Individual: First Series (1899) and then The World and the Individual: Second Series (1901). ${ }^{9}$ Peirce offered high praise for the second volume when he stated: "I will say hic et nunc that the volume has cut off a big piece of the road that it remains for Philosophy to travel before she will join company with the rest of the peaceable sciences." ${ }^{10} \mathrm{He}$ added, "Royce's 'The World and the Individual' will stand a prominent milestone upon the highway of philosophy."11 And in a letter to William James he said, "The ideas are very beautiful." ${ }^{12}$ Following these reviews, Peirce actively worked his way through Royce's recent writings.

As might be expected, Peirce often found fault with Royce's logic. In a 1902 letter to Royce he stated: "Underneath your logic which I cannot approve there is a nearly parallel stream of thought perfectly sound."13 This comment is repeated in a 1909 manuscript: " The World and the Individual, [is] a work not free from faults of logic, yet valid in the main." 14

71902 is important. Peirce and Royce corresponded. ${ }^{15}$ The letters and an invitation to Royce to spend time at the Peirce home in Milford in "cooperative" study ${ }^{16}$ indicate how seriously Peirce took Royce's ideas.

8 In the Lowell Lectures of 1903 (Lecture III, draft 3) Peirce named an author who assisted him in the effort to show the mistake of nominalism, which is the effort "to resolve everything in our thoughts into those two elements [of Firstness and Secondness alone]" (CP 1.343 (G-1903-2a)). That author was Josiah Royce, who "in his great work The World and the Individual has done much to breakup this mistake" (CP 1.343 (G-1903-2a)).

European Journal of Pragmatism and American Philosophy, VIII-2 | 2016 
9 In 1905, Peirce even states that "Mr. Royce [...] impresses me quite decidedly as a pragmatist” (EP II:361 (Ms. 908 [1905])).

In the 1906 "Issues of Pragmatism," Peirce acknowledged the aid received from Royce's World and Individual (CP 5.402n3 (G-1905-1b [1906])). Peirce repeated his praise again in 1909. He admired the concept of "the Reality, [sic] of the Absolute, nearly as it has been set forth [...] by Royce in his The World and the Individual, a work [...] valid in the main" (CP 5.358n1 (G-1909-1)).

11 This very brief chronology demonstrates that Peirce thought seriously about what Royce wrote. Peirce appears to have taken into his own thought elements from those writings.

\section{Royce's Influence}

A common manner of organizing Peirce's work is around the concept of realism. ${ }^{17}$ Peirce stated that the question of realism is "whether laws and general types are figments of the mind or are real" (CP 1.16 (G-c.1897-1)). The questions of realism are connected with the logic of relatives, pragmatism, evolution, objective idealism, continuity, and semiotics sometimes one feels that everything in Peirce's thought is interconnected, as he said himself: "a very snarl of twine" (CP 6.184 (G-c.1911-1)). This discussion will focus on aims, purposes and continuity.

The earliest mention of an aim or purpose by Peirce I can find is:

The agapastic development of thought should, if it exists, be distinguished by its purposive character, this purpose being the development of an idea. We should have a direct agapic or sympathetic comprehension and recognition of it by virtue of the continuity of thought. I here take it for granted that such continuity of thought has been sufficiently proved by the arguments used in my paper on the "Law of Mind" in The Monist of last July. (CP 6.315 (G-18911e [1893]))

While one immediately sees parallels to Royce's thought, one can also see that this notion of purpose could have grown from Peirce's development of his realism and his thought on evolution and continuity. Obviously, the concept of purpose is not unique to Royce or Peirce.

Max Fisch chronicled Peirce's realist development in his essay "Peirce's Progress from Nominalism toward Realism" (Fisch 1986: 184-200). As part of this chronology, Fisch (1986: 189) mentioned the 1885 "provocative" book by Josiah Royce, The Religious Aspect of Philosophy. Peirce's review of this work is a place to begin our discussion. A quick read of the review demonstrates easily that Peirce took seriously what Royce wrote. Peirce was working his way through Royce's thinking, although he rejected much of what was presented. The review's discussion of Royce's thoughts on an aim or ultimate end - we might say purpose - is something that reappears in Peirce's writings.

If the term 'purpose ${ }^{18}$ is used as a lens through which to consider the term 'application' in the following quotation, we see how in April, 1900, Peirce was refining his pragmatic maxim.

[i]n my youth I wrote some articles to uphold a doctrine I called Pragmatism, namely, that the meaning and essence of every conception lies in the application that is to be made of it. That is all very well, when properly understood. I do not intend to recant it. But the question arises, what is the ultimate application. (Peirce 1966: 332) 
17 A discussion of ultimate application seems very Roycean. Peirce began to understand that actions require some end or purpose. At this time, Peirce revised the pragmatic maxim to include the notion of purpose, a central element in Royce's thought.

A place to begin a more specific discussion of how Peirce's thinking changed is the April, 1900, Nation review of The World and the Individual: First Series. It opened with Peirce stating that the purpose of the volume "is to say what it is that we aim at when we make any inquiry or investigation - not what our ulterior purpose may be, nor yet what our special effort is in any particular case, but what the direct and common aim of all search for knowledge is" (CP 8.100 (N-1900-15)). Peirce saw that "Prof. Royce reaches his conclusion by analyzing the nature of the purpose of an idea" (CP 8.105 (N-1900-15)).

And in a draft of the review, Peirce stated,

[...] in the same pragmatistic spirit, Prof. Royce holds that the Internal Meaning of an idea is a Purpose, obscurely recognized in consciousness, partially fulfilled in being recognized but mainly unfulfilled and ill-understood in itself. The external meaning lies in the fulfillment of the purpose. (CP 8.119 [G-c.1902-4] a draft of The World and the Individual review) ${ }^{19}$

In a letter to Christine Ladd-Franklin (most likely from late 1903), Peirce stated:

Royce's opinions as developed in his 'World and Individual' are extremely near to mine. His insistence on the element of purpose in intellectual concepts is essentially the pragmatistic position. (Ladd-Franklin 1916: 720) ${ }^{20}$

21 After the review of The World and the Individual, while continuing his correspondence with Royce, Peirce writes more extensively on purpose. Purpose as a concept become more prominent. In the 1902 entry on Pragmatism in James Mark Baldwin's Dictionary of Philosophy and Psychology, ${ }^{21}$ Peirce wrote about the same kind of transition in his thinking, this time using the term 'end.'

If it be admitted [...] that action wants an end, and that that end must be something of a general description, then the spirit of the maxim itself, which is that that we must look to the upshot of our concepts in order rightly to apprehend them, would direct us towards something different from practical facts, namely, to general ideas, as the true interpreters of our thought. (Peirce 1972: 301)

The upshot is that Peirce began to see a connection between general concepts and ends, or Royce might say - purposes. Peirce incorporated into the pragmatic maxim the concept of purpose that is evident in Royce's writings.

Peirce's reading of Royce led him to articulate a fourth grade of clearness ${ }^{22}$ which comes when a concept, a conceived action, is thought of in terms of its purpose. The importance of purpose can be seen in Peirce's $1902^{23}$ application to the Carnegie Institution seeking funding for thirty-six memoirs, wherein he states "[...] my paper of 1878 was imperfect in tacitly leaving it to appear that the maxim of pragmatism led to the last stage of clearness," and "I shall develop a fourth, and higher, grade of clearness, resulting from an appreciation of the intellectual relations of the definitum [the thing defined]." ${ }^{24}$ Further, Peirce agrees with Schiller (CP 5.494 (G-c.1907-1C)) and Royce (CP 8.115 (G-c.1900-2)) $)^{25}$ that meaning requires a purpose. Peirce recognized that "concepts are purposive" (CP 8.322 (Letter to F.C. S. Schiller, 10 September 1906)) and that "The elements of every concept enter into logical thought at the gate of perception and make their exit at the gate of purposive action, and whatever cannot show its passports at both those two gates is to be arrested as unauthorized by reason" (CP 5.212 (G-1903-1)). Vincent Colapietro $(1986)^{26}$ connects a fourth grade of clearness, namely purpose, to semiosis, a central 
element in Peirce's semiotic, sign theory. Peirce stated that the Pragmatic Maxim is "a far-reaching theorem solidly grounded upon an elaborate study of the nature of signs" (CP 8.191 (G-c.1904-3)). Peirce in this work is bringing together a revised Pragmatic Maxim, a fourth grade of clearness, purpose, and semiosis. This set of refinements is quite major. Royce may not have been the chief instigator of these changes, but Royce's writings provided Peirce with the stimulus and occasion for these changes. These changes could have come later without Royce.

In 1906, Peirce mentioned Royce's influence:

No doubt, Pragmaticism makes thought ultimately apply to action exclusively - to conceived action. But between admitting that and either saying that it makes thought, in the sense of the purport of symbols, to consist in acts, or saying that the true ultimate purpose of thinking is action, there is much the same difference as there is between saying that the artist-painter's living art is applied to dabbing paint upon canvas, and saying that that art-life consists in dabbing paint, or that its ultimate aim is dabbing paint. Pragmaticism makes thinking to consist in the living inferential metaboly of symbols whose purport lies in conditional general resolutions to act. As for the ultimate purpose of thought, which must be the purpose of everything, it is beyond human comprehension; but according to the stage of approach which my thought has made to it - with aid from many persons, among whom I may mention Royce (in his World and Individual), Schiller (in his Riddles of the Sphinx) as well, by the way, as the famous poet [Friedrich Schiller] (in his Aesthetische Briefe), Henry James the elder (in his Substance and Shadow and in his conversations), together with Swedenborg himself - it is by the indefinite replication of self-control upon self-control that the vir is begotten, and by action, through thought, he grows an esthetic ideal, not for the behoof of his own poor noddle merely, but as the share which God permits him to have in the work of creation. (CP 5.402n3 (G-1905-1b [1906]))

In this long passage, Peirce reiterated his corrective that the pragmatic maxim does not lead specifically to unique actions but to "conditional general resolutions to act" or conceived action. He once again asserted his realism. The use of the phrase "ultimate purpose" in this passage is a likely indicator of Royce's influence on Peirce. Furthermore, the statement that the ultimate purpose of thought is man's "share which God permits him [man] to have in the work of creation" echoes not only Royce but also Peirce own essay "Evolutionary Love" (CP 6.287-317 (G-1891-1e [1893], The Monist, January 1893)). Peirce moved in a Roycean direction.

We cannot ignore the aspect of this passage in "Issues of Pragmatism" (above) in which Peirce stated "it is by the indefinite replication of self-control upon self-control that the vir is begotten, and by action, through thought, he grows an esthetic ideal." The vir is problematic (Krolikowski 1964: 257-70), but some desired end or goal is clearly implied. This esthetic ideal seems to be Peirce's summum bonum, the ultimate goal or purpose of all thought and evolution, the embodiment of reasonableness. (The first use of the term summum bonum appears to be in the Minute Logic of 1902 (CP 1.575), shortly after the Royce review.) The esthetic ideal, the summum bonum, the embodiment of reasonableness itself and the end or goal of evolution and all thought cannot be conceived except as an echo of Royce and likely much more. This large set of ideas seems not to have been fully developed in the remaining years of Peirce's active career, but it is clear he wished to see them developed. 


\section{Conclusion} writings around the time of the publication of The World and Individual. For Peirce, the 1899-1902 time period is full of change in thought resulting from the re-examination of earlier positions. Peirce changed his Pragmatic Maxim to move away from actions to generals, conceived actions or dispositions. He developed his theory of signs, semiotic, to include purpose. ${ }^{27}$ These are all major shifts in Peirce's thought. These shifts brought the thinking of Peirce and Royce closer than many may have imaged.

The narrative presented here should give us a stronger sense of the interaction between Royce and Peirce. They appreciated each other's work. The voluminous correspondence on logic c.1902-1905 ${ }^{28}$ is another indicator that Peirce and Royce understood each other. We see in this narrative two fine philosophic minds in full dialogue. We gain a further sense of Peirce's appreciation for Royce's thought, and of course, as often stated, Royce's appreciation for Peirce's thought. Peirce went so far as to state, "I think Royce's conception in The World and the Individual (although I do not assent to the logic in that work) comes nearer to the genuine upshot of pragmaticism than any exposition that a pragmatist has given, - than any other pragmatist has given" (Ms. 284, p. 6 (c. September 1905)). We must begin to see Royce and Peirce as two workers in the same large field. James and Dewey are in this field, but Royce and Peirce were closer than the others.

The change in Peirce thought in c.1905 was sufficiently great that he went so far as to state:

If this analysis of the pragmatistic opinion is correct, the logical breadth of the term pragmatist is hereby enormously enlarged. For it will become predicable not only of Mr. Royce but also of a large section of the logical world, - perhaps the majority, - since ancient times. ${ }^{29}$ (EP 2.361 (Ms. 908, late 1905-early 1906))

Royce concluded that he could see himself as a pragmatist; he claimed to have developed "a sort of absolute pragmatism" (Royce 1968: 279). My conclusion is that Peirce was able to include Josiah Royce in the great company of pragmatists because, with the study of Josiah Royce's work, Peirce enlarged his notion of pragmatism. Josiah Royce had a very significant impact on Charles Peirce, which led to a re-evaluation and development of Peirce's thinking during the 1899-1902 time period and to a renewed appreciation for Royce as a pragmatist.

\section{BIBLIOGRAPHY}

Аввот Francis Ellington, (1890), Scientific Theism, The Way Out of Agnosticism, Boston, MA, Little, Brown \& Co.

ANDERSON R. Douglas, (2005), "Who's a Pragmatist: Royce and Peirce at the Turn of the Century," Transactions of the Charles S. Peirce Society, 41, 3, 467-81.

European Journal of Pragmatism and American Philosophy, VIII-2 | 2016 
AUXIER E. Randall, (2013), Time, Will, and Purpose, Chicago, IL, Open Court.

BALDWIN James, (1972), Dictionary of Philosophy and Psychology (excerpts) as reprinted in Charles S. Peirce: The Essential Writings, Edward C. Moore (ed), New York, Harper \& Row, Publishers.

BOLER F. John, (1963), Charles Peirce and Scholastic Realism, Seattle, WA, University of Washington Press.

BRENT Joseph, (1998), Charles Sanders Peirce, revised and enlarged edition, Bloomington, Indiana University Press.

CLENDENNING John, (1999), The Life and Thought of Josiah Royce, Nashville, Vanderbilt University Press [Madison, University of Wisconsin Press, 1985].

CLENDENNING John, (ed), (1970), The Letters of Josiah Royce, Chicago, University of Chicago Press.

ColAPIETRo Vincento, (1985), "Peirce's Attempt to Define Semiosis," Semiotics 1985 (Lanham, MD, University Press of American, 1986), 479-86.

FISCH Max, (1951), "Introduction," Classic American Philosophers, New York, Appleton-CenturyCrofts, Inc.

FISCH Max, (1986), Peirce, Semeiotic, and Pragmatism, Bloomington, IN, Indiana University Press.

FLOWER Elizabeth \& Murray MURPHEY, (1977), A History of Philosophy in America, vol. II, New York, Capricorn Books,

HINE Robert, (1992), Josiah Royce: From Grass Valley to Harvard, Norman, University of Oklahoma Press.

KROLIKOWSKI Walter, (1964), “The Peircean Vir," Studies in the Philosophy of Charles Sanders Peirce: Second Series, Edward Moore \& Richard Robin (eds.), Amherst, University of Massachusetts Press. KUKLICK Bruce, (1985), Josiah Royce: An Intellectual Biography, Indianapolis, IN, Hackett Publishing. LADD-FRANKLIN Christine, (1916), “Charles S. Peirce at the Johns Hopkins," The Journal of Philosophy, $13,26$.

MAHOWALD BRoIDY Mary, (1972), An Idealistic Pragmatism, The Hague, Martinus Nijhoff.

MISAK Cheryl, (2013), The American Pragmatists, Oxford, UK, Oxford University Press.

NAGL Ludwig, (2004), “Beyond Absolute Pragmatism," Cognitio, 5, 1, 44-74.

opPENHEIM Frank, (2004), “Josiah Royce, 1855-1916,” The Blackwell Guide to American Philosophy, Armen Maroobian and John Ryder (eds.), Cambridge, MA, Blackwell Publishing, 118-19.

OPPENHEIM Frank, (2005), Reverence for the Relations of Life, Notre Dame, IN, University of Notre Dame Press.

PEIRCE Charles S., (1889-1891), The Century Dictionary of the English Language, New York, The Century Company.

PEIRCE Charles S., (1931-35/1958), The Collected Papers of Charles Sanders Peirce, Vols. I-VI, ed. Charles Hartshorne \& Paul Weiss (Cambridge, MA: Harvard University Press, 1931-1935), Vols. VII-VIII, ed. Arthur W. Burks (Cambridge, MA: Harvard University Press, 1958).

PEIRCE Charles S., (1966 [1958]), Review of Clark University, 1889-1899: Decennial Celebration in Science (April 20, 1900), pp. 620-2, as reprinted in Charles S. Peirce: Selected Writings, Philip P. Weiner (ed.), New York, Dover Publications. 
PEIRCE Charles S., (1967), Annotated Catalogue of the Papers of Charles S. Peirce, ed. Richard Robin, Amherst, MA, University of Massachusetts Press.

PEIRCE Charles S., (1972), Charles S. Peirce: The Essential Writings, Edward C. Moore (ed.), New York, Harper \& Row, Publishers.

PEIRCE Charles S., (1976a), The New Elements of Mathematics, Carolyn Eisele (ed.), The Hague, Mouton Publishers.

PEIRCE Charles S., (1976b), Manuscripts and letters at Harvard University photocopied by Texas Tech University in 1976, with copies at the Institute for American Thought, Indiana University Purdue University Indianapolis.

PEIRCE Charles S., (1982-2010), The Writings of Charles S. Peirce: A Chronological Edition, Vols. I-VI, VIII, multiple editors (Bloomington, IN, 1982-2010).

PEIRCE Charles S., (1992, 1998), The Essential Peirce: Selected Philosophical Writings, 2 volumes, Peirce Edition Project, Bloomington, IN, Indiana University Press.

PFEIFER David, (1971), The Summum Bonum in the Philosophy of C. S. Peirce, Ph.D. dissertation, University of Illinois.

PFEIFER David, (2011), “Inquiry and the Fourth Grade of Clearness” [nordprag.org/papers/ Pfeifer.pdf].

PFEIfER David, (2014), “The Primacy of Procreative Action in Peirce's Semiosis," Semiotics 2013, Charlotte, VA, Philosophy Documentation Center, 107-16.

ROYCE Josiah, (1885), The Religious Aspect of Philosophy, New York, Houghton, Mifflin \& Co.

ROYCE Josiah, (1899), The World and the Individual: First Series, New York, The Macmillan Company.

ROYCE Josiah, (1901), The World and the Individual: Second Series, New York, The Macmillan

Company.

ROYCE Josiah, (1905), "The Relation of the Principles of Logic to the Foundations of Geometry,"

Transactions of the American Mathematical Society, 24, 353-415.

ROYCE Josiah, (1968 [1913]), The Problem of Christianity, Chicago, University of Chicago Press.

\section{NOTES}

1. Clendenning 1999; Hine 1992; Kuklick 1985.

2. Brent 1998.

3. I became aware of this passage through the Douglas Anderson article cited above.

4. Note that Misak mistakenly says that Royce "was taught by Peirce" (p. 81) at Johns Hopkins University. Royce was at Johns Hopkins 1876-1878, receiving his Ph.D. in 1878. In August, 1878, Royce was in California. Peirce taught at Johns Hopkins 1879-1884. Nagl, in footnote 2 of his essay, indicates that Peirce became "interested" in Royce's thought. I wish to take a stronger stand.

5. In 1891, Peirce and Royce disagreed violently in the Francis Ellington Abbot controversy over Abbot's book, Scientific Theism, The Way Out of Agnosticism. The incident does not show the best side of any of the participants. I will ignore this incident, since it adds nothing to the present discussion. 
6. The focus of this paper is quite narrow. A separate and much longer paper could easily be done on how Royce may have influenced Peirce's pragmatism.

7. Royce was not in attendance. One desires to know what Peirce thought of Royce's paper.

8. Ms. 1369, published in CP 8.39-54 (in part), W 5:221-4, and EP I: 229-41. Manuscripts are cited by the Richard Robbin's catalogue number; CP refers to The Collected Papers by volume and paragraph number; W refers to the Writings of Charles S. Peirce: A Chronological Edition by volume and page number; and EP refers to the Essential Peirce by volume and page number. See works cited for complete bibliographic information.

9. Peirce's review of the first series is published at CP 8.100-16 (N-1900-15; G-C.1900-2), which is a compilation of the review and associated manuscripts. Peirce's review of the second series is published at CP 8.117 (in part) [except 117n10 and 117n12, 8.120 (in part)] and CP 8.126-30 which are from the published review (N-1902-10). See G-c.1902-4 for selections from alternative drafts printed with the above.

10. CP 8.117n10 (Letter from Peirce to Royce, 27 May 1902, on The World and the Individual: Second Series).

11. CP 8.117 (N-1902-10, review in The Nation.)

12. CP 8.277 (Letter to William James, 12 June 1902).

13. CP 8.117n12 (Letter to Josiah Royce, 27 May 1902).

14. CP 5.358n1 (G-1909-1).

15. See Clendenning (1970: 426-7, 435-8). See CP 8.117 n10 \& n12 (27 May 1902) plus CP 8.122 n19 (28 May 1902).

16. Peirce invited Royce to spend the summer of 1902 in Milford, PA, for "cooperative study of Logic, on my [Royce's] part, and of Hegel, on yours [Peirce's]" (Clendenning 1970: 436 (20 June 1902)). Royce did not accept. Another series of letters took place in 1905 (Clendenning 1970: 488-9, 489-90, and 490-2).

17. An early and useful study of Peirce's realism is Boler 1963. The volume has several references to Royce indicating Royce's awareness of Peirce's realism. See especially Boler (1963: 38, n.4).

18. Peirce wrote definitions for The Century Dictionary of the English Language (Peirce 1889-1891). He supplied some material for 'applicable' and 'application' (Peirce 1889-1891: 274); wrote several parts of 'end' (Peirce 1889-1891: 1917); but did not provide anything for 'purpose' (Peirce 1889-1891: 4858). Peirce was quite familiar with the contents of The Century Dictionary; so it is fair to assume he knew of these definitions. In 'application' is found "The act of applying a general principle;" in 'end' Peirce wrote "That for which anything exists or is done; a result designed or intended; ultimate object or purpose;" and in 'purpose' is "Import; meaning; purport; intent."

19. Again, Anderson (2005: 473) called this quotation to my attention.

20. Christine Ladd-Franklin, (1916), "Charles S. Peirce at the Johns Hopkins," The Journal of Philosophy, 13, 26 (21 December), 720. The letter is not dated in the publication, but internal evidence indicates that it written after mid-1903.

21. Baldwin wrote Peirce about doing entries for the Dictionary on 9 October 1900.

22. At times Peirce speaks of a fourth grade of clearness; at other times he seems to include purpose in the third grade of clearness. Peirce's final decision on a fourth grade of clearness is not evident. I will speak of the fourth grade simply for ease in exposition of my theme.

23. Note the year: it is the same as the review of The World and the Individual and during the time when Peirce and Royce were corresponding.

24. Carnegie Foundation Application (L75), reprinted in part in Peirce 1976a, vol. 4: 30.

25. See Ladd-Franklin (1916: 720).

26. Also see Pfeifer 2011.

27. David Pfeifer (2013: 107-16).

28. See the letters in L385 of Peirce manuscripts (Peirce 1976b), and the letters from Royce in Clendenning 1970. 
29. Note should also be made that Peirce praises Royce's work in logic. Witness Ms. 816A, p. 1, a discussion of Royce 1905. Context and correspondence place discussion as late 1905 or possibly early 1906. Peirce states: "Prof. Royce has shown discernment in devoting so much as he has to the study of these [A. B. Kempe's] conceptions, and his memoir is unquestionably of very considerable value."

\section{ABSTRACTS}

A common view is that Charles Peirce influenced Josiah Royce. This paper demonstrates that Josiah Royce influenced Charles Peirce. A chronology is presented, followed with a brief description of a change in Peirce's thinking from studying the writings of Royce.

\section{AUTHOR}

\section{DAVID E. PFEIFER}

Indiana University - Purdue University Indianapolis

depfeife[at]iupui.edu 